\title{
PERTUMBUHAN DAN PRODUKSI DUA VARIETAS KENTANG (Solanum tuberosum L.) PADA DUA KETINGGIAN TEMPAT
}

\section{GROWTH AND PRODUCTION OF TWO VARIETIES OF POTATO (Solanum tuberosum L.) ON TWO LEVEL ALTITUDES}

\author{
Benjamin H. Mailangkay1), Jeanne M. Paulus'2), dan Johannes E.X. Rogi2) \\ 1)Balai Pengawasan dan Sertifikasi Benih Tanaman Pangan dan Hortikultura Provinsi Sulawesi Utara \\ 2)Fakultas Pertanian Unsrat Manado
}

\begin{abstract}
This study aimed to examine the growth and production of potato crop varieties and varieties Granola Supejhon on two altitude, which is $750 \mathrm{~m}$ above sea level and $1200 \mathrm{~m}$ above sea level, studies using randomized block design with two factors. The first factor is the Granola variety and Supejhon. The second factor is the altitude, which is $750 \mathrm{~m}$ above sea level and $1200 \mathrm{~m}$ asl. The results of this study indicate that the rate Crop Growth Rate (LTT) and the Tuber Growth Rate (LTU) of Supejhon Granola varieties have a much higher altitude $1200 \mathrm{~m}$ asl (Modoinding) compared with altitude $750 \mathrm{~m}$ asl (Langowan). The altitude effect on the number of tubers / plant and production / plot, otherwise varieties had no effect on the number of tubers / plant, weight of tubers / plot and production / plot, and there is no interaction between variety and altitude. At altitude $750 \mathrm{~m}$ asl, both varieties yield an average production of tubers / plot of $1343.20 \mathrm{~g}(1.34 \mathrm{~kg})$, whereas the altitude of $1200 \mathrm{~m}$ asl generate 7462.18 $\mathrm{g}(7.46 \mathrm{~kg})$. Based on the average, the weight of tubers / plant and production / plots at very low reached by the two varieties of Granola and Supejhon well, so that the two varieties are not recommended to be cultivated at altitude $750 \mathrm{~m}$ above sea level. Further research is needed to examine other potato varieties that can be cultivated in areas with altitude of $750 \mathrm{~m}$ asl.
\end{abstract}

Keywords: Potato, growth, production, level altitudes

\begin{abstract}
ABSTRAK
Penelitian ini bertujuan untuk mengkaji pertumbuhan dan produksi tanaman kentang varietas Granola dan varietas Supejhon pada dua ketinggian tempat, yaitu $750 \mathrm{~m}$ dpl dan $1200 \mathrm{~m}$ dpl, penelitian menggunakan Rancangan Acak Kelompok dengan dua faktor. Faktor pertama adalah varietas Granola dan Supejhon. Faktor kedua adalah ketinggian tempat, yaitu $750 \mathrm{~m}$ dpl dan $1200 \mathrm{~m}$ dpl. Hasil penelitian ini menunjukkan bahwa Laju Tumbuh Tanaman (LTT) rata-rata dan Laju Tumbuh Umbi (LTU) rata-rata varietas Granola dan Supejhon memiliki nilai yang jauh lebih tinggi pada ketinggian tempat $1200 \mathrm{~m}$ dpl (Modoinding) dibandingkan dengan ketinggian tempat $750 \mathrm{~m}$ dpl (Langowan). Ketinggian tempat berpengaruh terhadap jumlah umbi/tanaman dan produksi/petak, sebaliknya varietas tidak berpengaruh terhadap jumlah umbi/tanaman, bobot umbi/petak dan produksi/petak, serta tidak terdapat interaksi antara varietas dan ketinggian tempat. Pada ketinggian tempat $750 \mathrm{~m}$ dpl, kedua varietas menghasilkan rata-rata produksi umbi/petak sebesar 1343,20 g (1,34 kg), sedangkan pada ketinggian tempat $1200 \mathrm{~m}$ dpl menghasilkan 7462,18 g (7,46 kg). Berdasarkan nilai rata-rata, bobot umbi/tanaman dan produksi/petak yang sangat rendah dicapai oleh kedua varietas baik Granola maupun Supejhon, sehingga kedua varietas tersebut tidak dianjurkan untuk dibudidayakan pada ketinggian $750 \mathrm{~m}$ dpl. Perlu dilakukan penelitian lanjutan untuk menguji varietas kentang lainya yang dapat dibudidayakan pada daerah dengan ketinggian tempat $750 \mathrm{~m}$ dpl.

Kata kunci: Kentang, pertumbuhan, produksi, ketinggian tempat
\end{abstract}

Eugenia Volume 18 No. 2 Agustus 2012 


\section{PENDAHULUAN}

Tanaman kentang (Solanum tuberosum L.) adalah termasuk tanaman sayuran yang berumur pendek (semusim). Saat ini kegunaan umbinya semakin banyak dan mempunyai peran penting bagi perekonomian Indonesia. Kebutuhan kentang semakin meningkat akibat pertumbuhan jumlah penduduk, juga akibat perubahan konsumsi di beberapa negara berkembang.

Salah satu kendala yang dihadapi di Indonesia ialah produktivitas kentangnya masih rendah dibandingkan dengan negara penghasil kentang lainnya, yaitu rata-rata 15 ton ha-1, meskipun menurut hasil penelitian potensi produksinya bisa mencapai 30 ton ha ${ }^{-1}$. Sementara Negara lain seperti Amerika Serikat produktivitasnya sekitar 38 ton ha, Selandia Baru 35 ton ha ${ }^{-1}$, Jepang 33 ton ha- ${ }^{-1}$ dan Belanda 37 ton ha $^{-1}$ (FAO, 1998 dalam Gunarto 2003).

Provinsi Sulawesi Utara terdapat 3 (tiga) Kabupaten yang menghasilkan kentang yaitu Kabupaten Minahasa Selatan, Bolaang Mongondow dan Bolaang Mongondow Timur. Berdasarkan data BPS dan Direktorat Jenderal Hortikultura bahwa Tahun 2011, luas panen kentang di Indonesia 59.882 ha, produksi 955.488 ton dengan produktivitas rata-rata 15,96 ton/ha. Sedangkan di Sulawesi Utara di tahun yang sama luas panen kentang 7.905 ha, produksi 114.548 ton dan produktivitas 14,49 ton/ha.

Kecamatan Modoinding Desa Linelean terletak pada ketinggian $1.200 \mathrm{~m}$ dpl merupakan sentra produksi tanaman kentang di Sulawesi Utara dan Kecamatan Langowan Barat Desa Paslaten terletak pada ketinggian $750 \mathrm{~m}$ dpl dimana banyak petani di daerah ini suka bertanam tanaman kentang. Secara nasional kentang varietas Granola banyak di tanam oleh para petani, sedangkan di Sulawesi Utara banyak petani yang menanam kentang varietas Supejhon.

Ciri iklim wilayah Langowan rata-rata adalah suhu udara $21,1^{\circ} \mathrm{C}$, kelembaban udara $87,7 \%$, radiasi $22,1 \mathrm{MJ} \mathrm{m}^{-2}$ hari-1. Adapun curah hujan ialah $222,0 \mathrm{~mm} /$ bulan. Tipe iklim daerah ini menurut klasifikasi Oldemanialah C1.
Wilayah Modoinding ciri iklim rata-rata adalah suhu udara $18-21^{\circ} \mathrm{C}$, kelembaban udara $88,5-96 \%$. Kecepatan angin 1,2 m/det, radiasi 17 $19,8 \mathrm{MJ} \mathrm{m}^{-2}$ hari-1 Adapun curah hujan adalah 211,66-241,92 mm/bulan. Tipe iklim daerah ini menurut klasifikasi Oldeman adalah A1 (Rogi, 2008).

Hasil penelitian Edi (2001), bahwa ketinggian tempat berpengaruh nyata terhadap pertumbuhan, produksi dan keuntungan finansial yang di terima petani. Usaha tani kentang pada ketinggian $1500 \mathrm{~m}$ dpl lebih menguntungkan bila dibandingkan dengan ketinggian $800 \mathrm{~m}$ dpl.

Menurut Handayani (2009), usaha meningkatkan produksi kentang dapat dilakukan selain melalui intensifikasi, diperlukan juga upaya ekstensifikasi pada lahan yang sesuai. Strategi yang harus ditempuh dalam upaya peningkatan pertanaman kentang ialah pengembangan penanaman yang diarahkan ke dataran yang lebih rendah, yaitu dataran medium (300 sampai $700 \mathrm{~m}$ diatas permukaan laut) yang arealnya tersedia cukup luas di Indonesia.

Berdasarkan animo masyarakat tersebut di atas dalam penanaman kentang yang belum mengetahui varietas yang sesuai dengan keadaan tempat maka perlu dilakukan penelitian tentang pertumbuhan dan produksi dua varietas kentang pada dua ketinggian tempat yang berbeda. Belum adanya data dan informasi tentang pertumbuhan dan produksi tanaman kentang pada dua ketinggian tempat yang berbeda.

Penelitian ini bertujuan untuk mengkaji pertumbuhan dan produksi dua varietas kentang pada dua ketinggian tempat yang berbeda.

\section{METODE PENELITIAN}

Penelitian ini dilaksanakan pada dua ketinggian tempat yang berbeda yaitu di Desa Paslaten Kecamatan Langowan Barat Kabupaten Minahasa, dengan ketinggian tempat $750 \mathrm{~m}$ dpl dan Desa Linelean Kecamatan Modoinding Kabupaten Minahasa Selatan dengan ketinggian $1200 \mathrm{~m}$ dpl. Penelitian ini dilaksanakan pada bulan Maret-Juni 2012. 
Bahan yang digunakan dalam penelitian ini ialah benih kentang dua varietas yaitu Granola dan Supejhon kelas benih G4 atau sudah dimurnikan dengan berat $45-60 \mathrm{~g}$ per butir (ukuran panjang tunas 2-3 cm dan jumlah tunas 3-5 buah) yang sudah melewati masa dormansi (3-4 Bulan) dan siap tanam, pupuk kandang, pupuk NPK Ponska, Sp 36, Urea.

Penelitian dilaksanakan menggunakan Rancangan Acak Kelompok (RAK) Pola Faktorial. Dengan 2 (Dua ) Faktor yaitu : Faktor I = Varietas Kentang. V1 = Varietas Granola, V2 = Varietas Supejhon, Faktor $\|=$ Ketinggian Tempat, $\mathrm{K} 1=$ Ketinggian $750 \mathrm{~m}$ dpl, K2 = Ketinggian $1200 \mathrm{~m}$ dpl.

Laju Tumbuh Tanaman (LTT) rata-rata diamati dengan menghitung bobot kering tanaman sejak tanaman berumur 2 minggu setelah tanam (HST) sampai dengan 77 hari setelah tanam (HST) atau 11 minggu setelah tanam. LTT dihitung dengan menggunakan Formula Gardner et.al., 1991. Laju Tumbuh Umbi (LTU) rata-rata diamati dua minggu sekali, yaitu laju penambahan bobot kering umbi per tanaman persatuan waktu rata-rata 2 minggu yang menggambarkan peningkatan ratarata bobot kering umbi per tanaman per hari ratarata dalam periode tujuh harian (Nurmayulis dan Maryati, 2008). Jumlah umbi per tanaman diamati pada saat panen. Bobot umbi basah per tanaman diamati pada saat panen (g). Produksi per petak diamati pada saat panen $(\mathrm{g})$.

Data LTT rata-rata dan LTU rata-rata diuji dengan menggunakan analisis regresi. Data jumlah umbi per tanaman, bobot umbi per tanaman dan produksi per petak dianalisis dengan menggunakan analisis sidik ragam, apabila terdapat perbedaan diantara perlakuan maka akan dilakukan dengan Uji Beda Nyata Terkecil (BNT)

\section{Pengolahan Tanah}

Sebelum areal diolah terlebih dahulu dibersihkan dari rerumputan dan pengolahan tanah dilakukan dua kali, yang pertama dilakukan dengan mencangkul tanah sedalam kurang lebih $30 \mathrm{~cm}$ dengan cara membalikan tanah kemudian dibiarkan selama 15 hari. Pengolahan kedua dilaksanakan dengan tujuan menghancurkan dan menghaluskan tanah. Setelah pengolahan tanah selesai, dibuat bedengan dengan ukuran lebar 1,3 m x $11 \mathrm{~m}$ dan tinggi $40 \mathrm{~cm}$. Setiap bedengan ditanam 4 baris atau jalur tanaman dengan jarak antara baris pertanaman $70 \mathrm{~cm}$ dan jarak antar tanaman dengan baris $30 \mathrm{~cm}$ antar bedengan $100 \mathrm{~cm}$ yang berbentuk saluran air sedangkan saluran air antar petak percobaan sedalam $40 \mathrm{~cm}$. Jumlah tanaman dalam satu bedengan 75 tanaman.

\section{Penanaman dan Pemupukan}

Penanaman dilakukan pada sore hari. Sebelum dilakukan penanaman terlebih dahulu dibuat lubang tanam sedalam $7-10 \mathrm{~cm}$ dengan jarak tanam $70 \mathrm{~cm} \times 30 \mathrm{~cm}$. Sebelum penanaman dilakukan aplikasi pemberian insektisida/nematode dengan cara ditabur untuk mengurangi resiko benih terinfeksi nematode maupun serangga yang lain. Masing-masing lubang dimasukan satu umbi benih dengan posisi benih dalam penanaman tunas menghadap ke atas dan selanjutnya ditutup dengan tanah kira-kira setebal $5 \mathrm{~cm}$.

Pemberian pupuk sesuai jenis, waktu dan dosis. Pemupukan dasar menggunakan pupuk kandang matang sebanyak $10.000 \mathrm{~kg} / \mathrm{ha}$ atau pertanaman $1,5 \mathrm{~kg}$ di campur dengan tanah di sekitar lubang tanam sedalam $25 \mathrm{~cm}$ perlubang. NPK Ponska $250 \mathrm{~kg} / \mathrm{ha}$ atau per tanaman $37 \mathrm{~g}$, Urea $200 \mathrm{~kg} / \mathrm{ha}$ atau per tanaman $30 \mathrm{~g}$ dan SP 36 $200 \mathrm{~kg} / \mathrm{ha}$ atau per tanaman $30 \mathrm{~g}$. Pada umur 21 hari setelah tanam diberikan pemupukan susulan I NPK Ponska $100 \mathrm{~kg} / \mathrm{ha}$ atau per tanaman $15 \mathrm{~g}$, Urea $100 \mathrm{~kg}$ atau per tanaman $15 \mathrm{~g}$ dan SP 36200 $\mathrm{kg} / \mathrm{ha}$ atau per tanaman $30 \mathrm{~g}$, kemudian dilanjutkan dengan pembumbunan I untuk mencegah kentang muncul dipermukaan. Pembumbunan II dilakukan pada umur 45 hari sesudah tanam. Pemupukan susulan ke II NPK Ponska $100 \mathrm{~kg} / \mathrm{ha}$ atau per tanaman15 g, Urea $150 \mathrm{~kg} / \mathrm{ha}$ atau per tanaman 22 $\mathrm{g}$ dilanjutkan dengan pembumbunan.

\section{Pengendalian Hama dan Penyakit}

Pengendalian hama dan penyakit dilakukan secara intensif. Pada saat tunas kelaur dari permukaan tanah mulai 14 hari dilakukan penyemprotan insektisida Decis dan fungisida Deconil dengan dosis sesuai anjuran, untuk 
bakterisida Agrept sebelum tanam dan selang 2 minggu sesuai dosis.

\section{Panen}

Pemanenan dilakukan setelah ada pengamatan secara periodik terhadap perkembangan fisik tanaman saat panen yang tepat pada tanaman kentang ditandai dengan perubahan warna daun dari hijau segar menjadi kekuningan. Dapat juga dilakukan pengujian tingkat ketuaan dengan cara mengesekkan kulit umbi kentang dengan lainnya. Untuk varitas Granola dipanen umur 98 hari setelah tanam dan untuk varitas Supejhon 109 hari setelah tanam.

\section{HASIL DAN PEMBAHASAN}

\section{Laju Tumbuh Tanaman (LTT) Rata-rata}

Pertumbuhan tanaman merupakan penimbunan bahan kering per satuan luas per satuan waktu. Bahan kering tanaman merupakan gambaran translokasi fotosintat ke seluruh bagian tanaman, sehingga Laju Tumbuh Tanaman (LTT) sangat ditentukan oleh laju fotosintesis yang maksimal.

Perkembangan LTT rata-rata dua mingguan pada dua varietas kentang yaitu Granola dan Supejhon pada dua ketinggian tempat $(750 \mathrm{~m}$ dpl dan $1200 \mathrm{~m} \mathrm{dpl)} \mathrm{selama} \mathrm{periode} \mathrm{tumbuh} 28$ sampai 70 HST memperlihatkan pola hubungan kuadratik (Gambar 1a dan 1b).

Pada Gambar 1a, terlihat bahwa kedua varietas baik Granola maupun Supejohn memiliki pola LTT yang sama. LTT kedua varietas tersebut meningkat mulai pada umur 28 HST hingga umur 56 HST, kemudian perlahan-lahan mengalami penurunan sampai umur $70 \mathrm{HST}$. Varietas Supejohn memiliki LTT yang lebih tinggi jika dibandingkan dengan varietas Granola. LTT tertinggi dicapai oleh varietas Supejhon pada umur 42 HST sampai 56 HST, yaitu sebesar 0,001058 g $\mathrm{cm}^{-2} \mathrm{hr}^{-1}$ dan $0,001021 \mathrm{~g} \mathrm{~cm}^{-2} \mathrm{hr}^{-1}$, sedangkan varietas Granola pada umur yang sama sebesar $0,000970 \mathrm{~g} \mathrm{~cm}^{-2} \mathrm{hr}^{-1}$ dan $0,000920 \mathrm{~g} \mathrm{~cm}^{-2} \mathrm{hr}^{-1}$.

Pada Gambar 1b, terlihat juga bahwa LTT kedua varietas baik Granola maupun Superjohn menunjukkan pola yang sama, yaitu LTT meningkat pada umur 42 HST sampai 56 HST, kemudian mengalami penurunan yang drastis sampai pada umur 70 HST. Menurunnya pertumbuhan tajuk pada umur 56 HST disebabkan oleh tanaman kentang memasuki fase pertumbuhan umbi yang maksimal pada umur 63 HST pada dua ketinggian tempat, baik pada $750 \mathrm{~m}$ dpl maupun $1200 \mathrm{~m}$ dpl (Gambar 3a dan Gambar 3b).

Varietas Supejohn memiliki nilai LTT yang lebih tinggi jika dibandingkan dengan varietas Granola. LTT tertinggi dicapai oleh varietas Supejhon pada umur 42 HST sampai 56 HST, yaitu masing-masing sebesar $0,002918 \mathrm{~g} \mathrm{~cm}^{-2} \mathrm{hr}^{-1}$ dan $0,002704 \mathrm{~g} \mathrm{~cm}^{-2} \mathrm{hr}^{-1}$, sedangkan varietas Granola pada umur yang sama sebesar $0,002637 \mathrm{~g} \mathrm{~cm}^{-2} \mathrm{hr}^{-1}$ dan $0,002309 \mathrm{~g} \mathrm{~cm}^{-2} \mathrm{hr}^{-1}$.

Nilai-nilai LTT yang lebih tinggi pada varietas Supejohn disebabkan oleh varietas tersebut memiliki umur tanaman yang lebih panjang yaitu 100-110 HST yang memiliki bobot brangkasan yang lebih tinggi, dibandingkan dengan varietas Granola yang dipanen pada umur 90-100 HST dan memiliki bobot brangkasan yang lebih rendah. Bobot brangkasan yang rendah akan menghasilkan hasil umbi yang rendah pula. Nilai LTT yang berbeda pada kedua varietas tersebut, seperti yang dikemukakan oleh Beukema dan van der Zaag (1979), terdapat dua tipe pertumbuhan tanaman kentang, yaitu : (1) tipe daur pendek, yang dicirikan dengan bobot brangkasan rendah, inisiasi umbi lebih awal, umur relatif pendek sehingga panen lebih cepat, dan menghasilkan umbi lebih rendah dari pada tipe daur panjang; (2) tipe daur panjang, dicirikan dengan bobot brangkasan besar, inisiasi umbi terlambat, umur lebih panjang, dan mampu menghasilkan umbi yang lebih tinggi dari pada tipe daur pendek.

Berdasarkan ketinggian tempat pada Gambar 2a dan 2b, terlihat bahwa LTT varietas Granola pada $750 \mathrm{~m}$ dpl memiliki nilai yang sangat kecil atau kurang dari $0,00097 \mathrm{~g} \mathrm{~cm}^{-2} \mathrm{hr}^{-1}$ dan $0,00092 \mathrm{~g} \mathrm{~cm}^{-2} \mathrm{hr}^{-1}$ pada umur 42 HST dan 56 HST. Sebaliknya, pada ketinggian tempat $1200 \mathrm{~m}$ dpl LTT varietas tersebut dapat mencapai nilai 0,0026 $\mathrm{g} \mathrm{cm}^{-2} \mathrm{hr}^{-1}$ dan $0,0023 \mathrm{~g} \mathrm{~cm}^{-2} \mathrm{hr}^{-1}$ pada umur 42 HST dan 56 HST. 


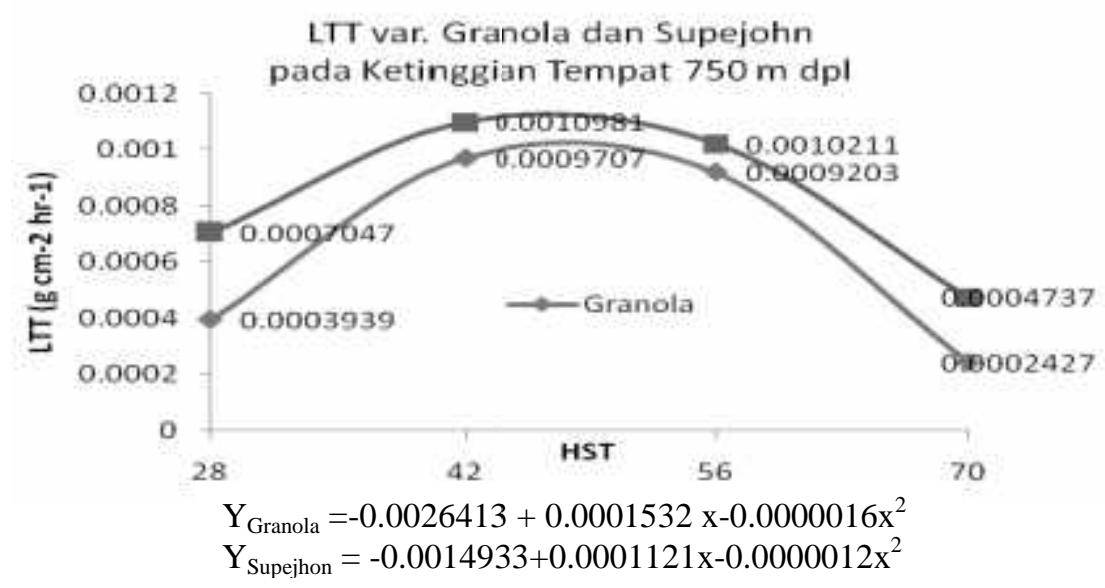

Gambar 1a. Perkembangan Laju Tumbuh Tanaman (LTT) rata-rata pada Ketinggian Tempat $750 \mathrm{~m}$ dpl

(Figure 1a. The Development of Crop Growth Rate (CGR) on Average at the Right Height $750 \mathrm{~m}$ Above Sea Level)

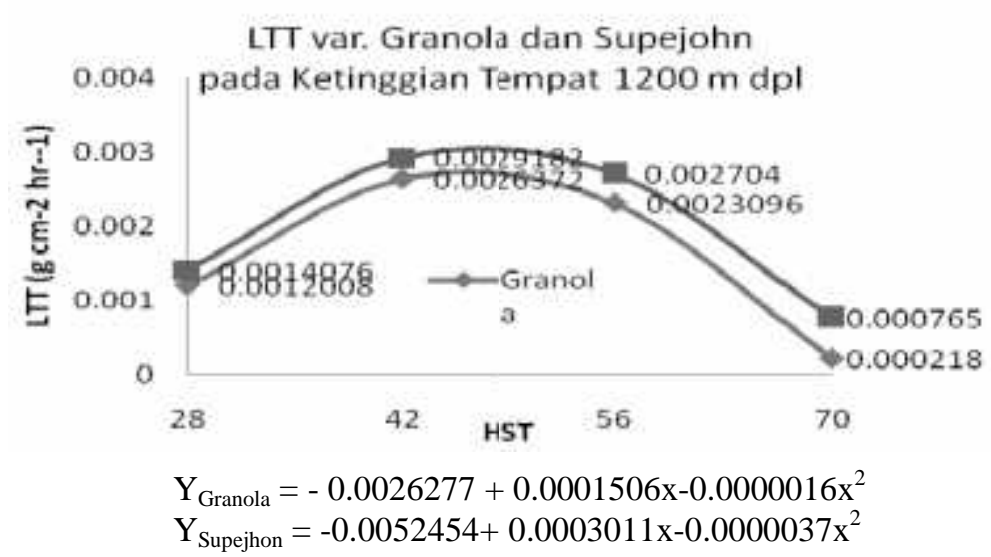

Gambar 1b. Perkembangan Laju Tumbuh Tanaman (LTT) rata-rata pada Ketinggian Tempat $1200 \mathrm{~m}$ dpl

(Figure 1b. The Development of Crop Growth Rate (CGR) on Average at the Right Height $1200 \mathrm{~m}$ Above Sea Level)

Hal yang sama juga berlaku pada varietas Supejhon, pada ketinggian tempat $750 \mathrm{~m}$ dpl nilai LTT jauh lebih rendah, yaitu sebesar $0,010 \mathrm{~g} \mathrm{~cm}^{-2}$ $\mathrm{hr}^{-1}$ pada umur 42 HST dan 56 HST, sedangkan pada ketinggian $1200 \mathrm{~m}$ dpl nilai yang dicapai adalah $0,0029 \mathrm{~g} \mathrm{~cm}^{-2} \mathrm{hr}^{-1}$ dan $0.0027 \mathrm{~g} \mathrm{~cm}^{-2} \mathrm{hr}^{-1} \mathrm{~g}$ $\mathrm{cm}^{-2} \mathrm{hr}^{-1}$ pada umur $42 \mathrm{HST}$ dan $56 \mathrm{HST}$.

Laju tumbuh tanaman yang rendah pada ketinggian tempat $750 \mathrm{~m}$ dpl dipengaruhi oleh faktor lingkungan, terutama suhu dan kelembaban. Menurut Midmore (1984), bahwa suhu tanah tidak hanya berpengaruh terhadap hasil umbi, tetapi berpengaruh juga terhadap saat tumbuh, saat inisiasi umbi, bentuk daun, jumlah daun, dan struktur percabangan. Suhu tanah siang hari dan malam hari yang tinggi akan menurunkan pertumbuhan tanaman.

\section{Laju Tumbuh Umbi (LTU) rata-rata}

Bobot kering umbi menggambarkan jumlah hasil fotosintesis (fotosintat) yang dialirkan dari sumber (source) ke organ penyimpan (sink). Pada tanaman umbi-umbian termasuk kentang, organ penyimpan tersebut adalah umbi.

Perkembangan LTU rata-rata dua mingguan pada dua varietas kentang yaitu Granola dan Supejhon pada dua ketinggian tempat $(750 \mathrm{~m}$ dpl dan $1200 \mathrm{~m} \mathrm{dpl)} \mathrm{selama} \mathrm{periode} \mathrm{tumbuh} 28$ sampai 70 HST memperlihatkan pola hubungan kuadratik (Gambar 3a dan 3b). 
Pada Gambar 3a, terlihat bahwa LTU varietas Granola memiliki nilai-nilai yang lebih tinggi dibandingkan dengan varietas Supejhon. LTU varietas Granola meningkat mulai umur tanaman 35 HST sampai dengan 63 HST, kemudian menurun sampai umur 91 HST. Nilai LTU tertinggi dicapai pada umur $63 \mathrm{HST}$ dengan nilai $0,5 \mathrm{~g} \mathrm{~cm}^{-2} \mathrm{hr}^{-1}$.
Pola yang sama berlaku untuk varietas Supejhon dimana LTU meningkat sejak umur 35 HST sampai 63 HST kemudian menurun hingga umur 91 HST. Nilai LTT tertinggi sebesar $0.36 \mathrm{~g} \mathrm{~cm}^{-2} \mathrm{hr}^{-1}$ pada umur 63 HST.

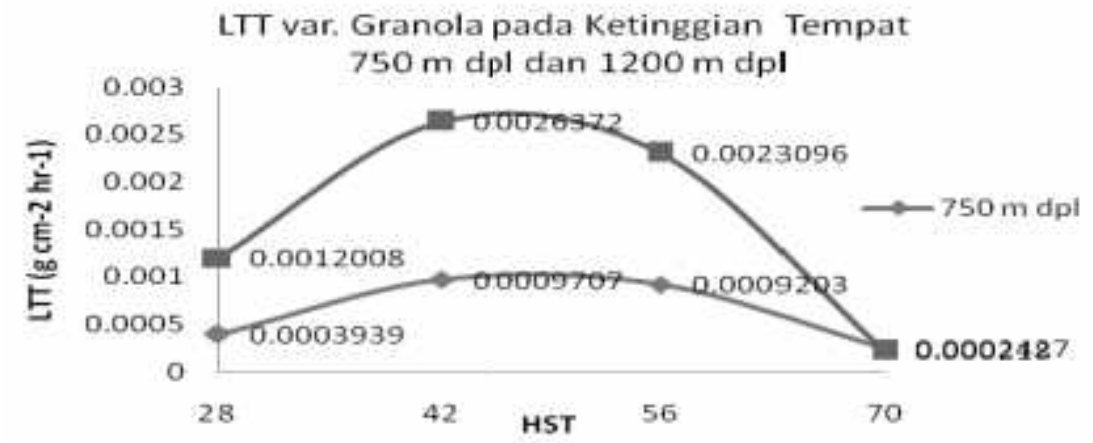

Gambar 2a. Perkembangan Laju Tumbuh Tanaman (LTT) rata-rata varietas Granola pada Ketinggian Tempat $750 \mathrm{~m}$ dpl dan $1200 \mathrm{~m}$ dpl

(Figure 2a. The Development of Crop Growth Rate (CGR) on Average Varieties of Granola at the Right Height $750 \mathrm{~m}$ Above Sea Level and 1200 Above Sea Level)

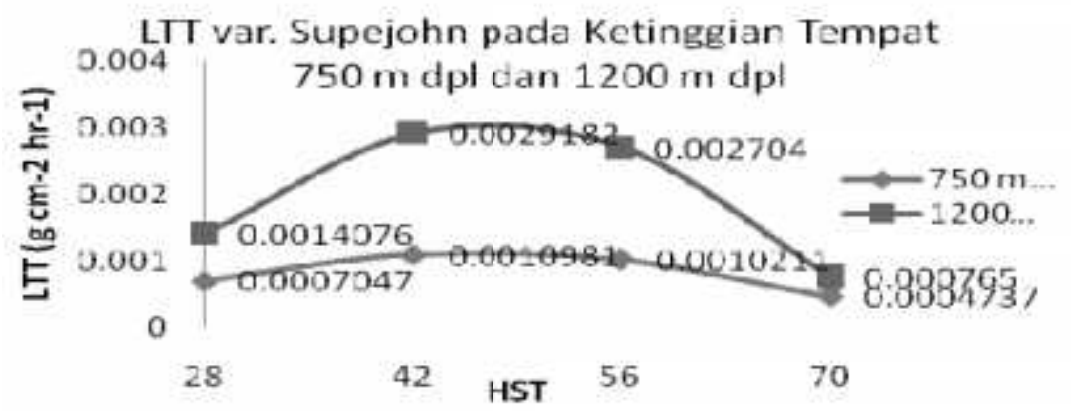

Gambar 2b. Perkembangan Laju Tumbuh Tanaman (LTT) rata-rata varietas Supejohn pada Ketinggian Tempat $750 \mathrm{~m}$ dpl dan $1200 \mathrm{~m}$ dpl

(Figure 2b. The Development of Crop Growth Rate (CGR) on Average Varieties of Supejohn at the Right Height $750 \mathrm{~m}$ Above Sea Level and $1200 \mathrm{~m}$ Above Sea Level)

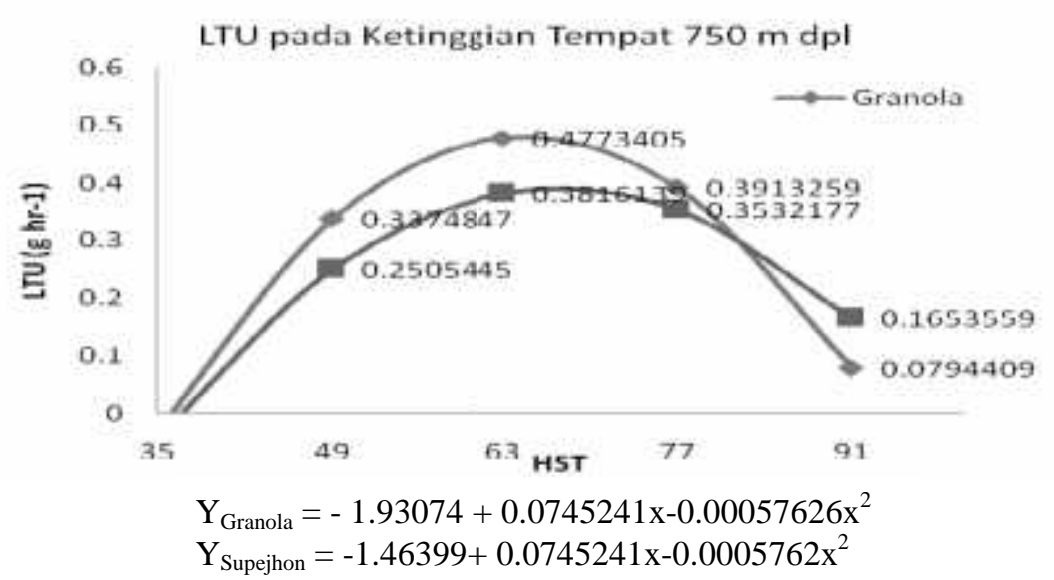

Gambar 3a. Perkembangan Laju Tumbuh Umbi (LTU) rata-rata varietas Granola dan Supejohn pada Ketinggian Tempat $750 \mathrm{~m}$ dpl

(Figure 3a. The Development of Tuber Growth Rate (TGR) on Average Varieties of Granola and Supejohn on the Right Height 750 m Above Sea Level) 
Pada Gambar 3b, terlihat bahwa LTU varietas Granola dan varietas Supejhon memiliki nilai-nilai yang sama atau garis kurva kedua varietas tersebut berimpit satu dengan yang lainnya. LTU kedua varietas meningkat mulai umur tanaman 35 HST sampai dengan 63 HST, kemudian menurun sampai umur 91 HST. Nilai LTU tertinggi dicapai pada umur 63 HST dengan nilai $1,6 \mathrm{~g} \mathrm{hr}^{-1}$ dan terendah pada umur 91 HST dengan nilai $0,50 \mathrm{~g} \mathrm{hr}^{-1}$.

Nilai LTU tertinggi pada umur 63 HST menggambarkan bahwa tanaman telah mengakhiri stadium pertumbuhan tajuk dan memasuki stadium penyempurnaan umbi (Dirjen Tanaman Pangan dan Hortikultura, 1997 dalam Pitojo, 2004). Menurut Beukema dan van der Zaag (1979) bahwa pada stadium pertumbuhan umbi (tuber growth) terjadi persaingan yang kuat antara umbi dengan bagian atas tanaman (shoot) yang sama-sama tumbuh dan sama-sama berperan sebagai penerima (sink).

Persaingan tersebut berhenti setelah pertumbuhan brangkasan mencapai maksimum dan hanya umbi yang berfungsi sebagai penerima, sedangkan brangkasan berubah menjadi sumber (source).

Pada Gambar 4a dan Gambar 4b, LTU kedua varietas baik Granola maupun Supejhon memiliki pola serta nilai-nilai yang sama. LTU ke dua varietas mencapai nilai yang jauh lebih tinggi pada ketinggian tempat $1200 \mathrm{~m}$ dpl dibandingkan dengan pada ketinggian tempat $750 \mathrm{~m}$ dpl.

Laju tumbuh umbi yang rendah pada ketinggian tempat $750 \mathrm{~m}$ dpl diduga karena dipengaruhi oleh suhu tanah yang tinggi. Menurut Midmore (1984), suhu tanah tidak hanya mempengaruhi hasil kentang, akan tetapi juga mempengaruhi saat tumbuh, saat inisiasi, bentuk daun, jumlah daun. Suhu tanah yang tinggi pada siang hari $\left(40^{\circ} \mathrm{C}\right)$ menurunkan laju pertumbuhan umbi.

Pengaruh suhu tanah maupun suhu udara yang tinggi terhadap bobot kering umbi mempunyai hubungan erat dengan pertumbuhan vegetatif tanaman. Dalam percobaan ini tergambar dari nilai-nilai LTT yang rendah dari kedua varietas kentang baik Granola maupun Supejohn pada ketinggian tempat $750 \mathrm{~m} \mathrm{dpl}$ menyebabkan nilai- nilai LTU yang rendah pula, sehingga mengakibatkan hasil umbi yang rendah. Sebaliknya, nilai-nilai LTT yang tinggi pada ketinggian tempat $1200 \mathrm{~m}$ dpl menyebabkan nilainilai LTU yang tinggi dan selanjutnya menghasilkan hasil umbi yang tinggi pula, terlihat dari bobot umbi per tanaman dan bobot umbi per petak yang lebih tinggi.

\section{Jumlah Umbi per Tanaman}

Hasil analisis statistik menunjukkan bahwa jumlah umbi per tanaman tidak dipengaruhi oleh varietas, namun dipengaruhi oleh ketinggian tempat. Interaksi antara varietas dan ketinggian tempat tidak nyata.

Dari hasil analisis terlihat bahwa varietas tidak berpengaruh terhadap rata-rata jumlah umbi per tanaman, namun pada ketinggian tempat $750 \mathrm{~m}$ dpl varietas Granola dan Supejohn memiliki jumlah umbi per tanaman yang lebih tinggi, yaitu masingmasing sebesar 9,89 dan 9,78 jika dibandingkan dengan yang di tanam pada ketinggian tempat $1200 \mathrm{~m}$ dpl sebesar 9,11 dan 7,95.

Dari hasil analisis terlihat bahwa pada ketinggian tempat $750 \mathrm{~m}$ dpl menghasilkan ratarata jumlah umbi per tanaman sebesar 9,83, sedangkan pada ketinggian tempat $1200 \mathrm{~m}$ dpl memiliki jumlah umbi per tanaman lebih rendah, yaitu sebesar 8,53 . Jika dihubungkan dengan bobot umbi per tanaman terlihat bahwa pada ketinggian tempat $750 \mathrm{~m}$ dpl dicapai jumlah umbi yang lebih banyak, namun ukuran umbinya kecil-kecil sehingga bobot umbi juga rendah.

\section{Bobot Umbi per Tanaman}

Hasil analisis statistik menunjukkan bahwa bobot umbi per tanaman tidak dipengaruhi oleh varietas, namun dipengaruhi oleh ketinggian tempat. Interaksi antara varietas dan ketinggian tempat tidak nyata.

Dari hasil analisis terlihat bahwa varietas tidak berpengaruh terhadap Bobot umbi per tanaman, namun pada ketinggian tempat $1200 \mathrm{~m}$ dpl varietas Granola dan Supejohn memiliki bobot umbi per tanaman yang jauh lebih tinggi dan memiliki nilaui yang sama, yaitu sebesar $7462 \mathrm{~g}$ jika dibandingkan dengan yang di tanam pada 
ketinggian tempat $750 \mathrm{~m}$ dpl sebesar $238,26 \mathrm{~g}$ dan $209,47 \mathrm{~g}$.

Dari hasil analisis terlihat bahwa pada ketinggian tempat $750 \mathrm{~m}$ dpl menghasilkan ratarata bobot umbi per tanaman sebesar $223,87 \mathrm{~g}$. Nilai tersebut sangat jauh lebih rendah jika dibandingkan dengan bobot umbi per tanaman pada ketinggian tempat $1200 \mathrm{~m}$ dpl, yaitu sebesar $7462,18 \mathrm{~g}$.

Hasil yang sangat rendah pada ketinggian tempat $750 \mathrm{~m}$ dpl dipengaruhi oleh suhu tanah yang tinggi, sesuai dengan hasil yang dilaporkan oleh Midmore (1984) bahwa suhu tanah yang tinggi pada dataran rendah berpengaruh terhadap bobot kering umbi dan memiliki hubungan yang erat dengan pertumbuhan vegetatif tanaman. Indeks panen pada tanaman kentang yang tumbuh pada suhu tanah yang lebih tinggi rata-rata $10 \%$ lebih rendah dibandingkan dengan kentang yang tumbuh pada suhu tanah yang lebih rendah.

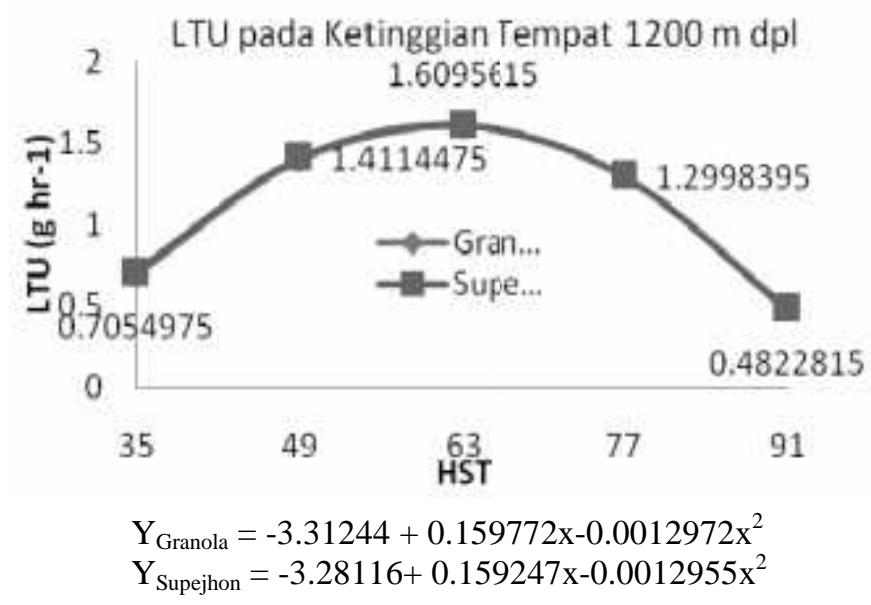

Gambar 3b. Perkembangan Laju Tumbuh Umbi (LTU) rata-rata varietas Granola dan Supejohn pada Ketinggian Tempat $1200 \mathrm{~m}$ dpl

(Figure 3b. The Development of Tuber Growth Rate (TGR) on Average Varieties of Granola and Supejohn on the Right Height 1200 m Above Sea Level)

LTU var. Granola pada Ketinggian Tempat $750 \mathrm{~m}$ dpl dan $1200 \mathrm{~m} \mathrm{dpl}$

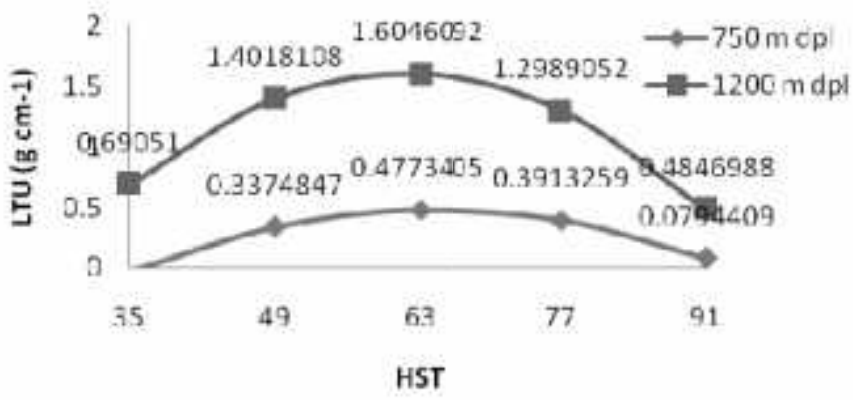

Gambar 4a. Perkembangan Laju Tumbuh Umbi (LTU) rata-rata varietas Granola pada Ketinggian Tempat 750 $\mathrm{m}$ dpl dan $1200 \mathrm{~m}$ dpl.

(Figure 4a. The Development of Tuber Growth Rate (TGR) on Average Varieties of Granola on the Right Height $750 \mathrm{~m}$ Above Sea Level and $1200 \mathrm{~m}$ Above Sea Level) 


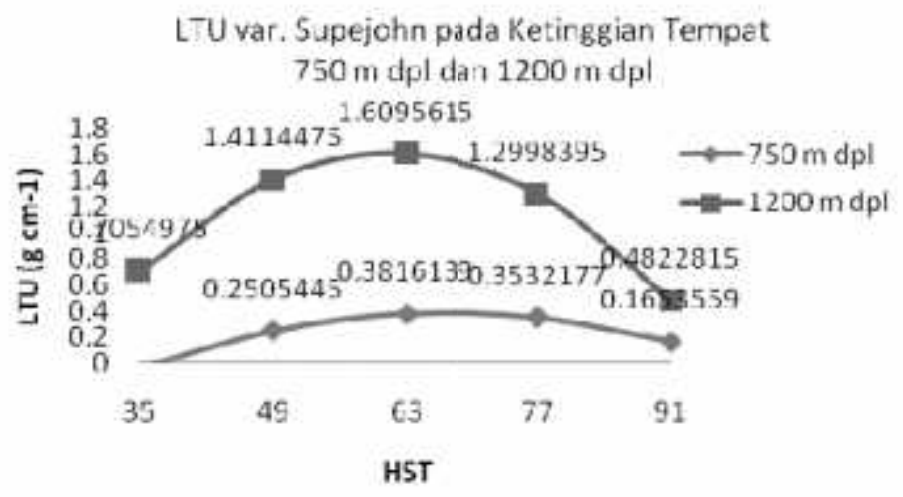

Gambar 4b. Perkembangan Laju Tumbuh Umbi (LTU) rata-rata varietas Supejohn pada Ketinggian Tempat $750 \mathrm{~m}$ dpl dan $1200 \mathrm{~m} \mathrm{dpl}$

(Figure 4b. The Development of Tuber Growth Rate (TGR) on Average Varieties of Supejohn on the Right Height $750 \mathrm{~m}$ Above Sea Level and $1200 \mathrm{~m}$ Above Sea Level)

\section{Produksi Umbi per Petak}

Hasil analisis statistik menunjukkan bahwa produksi umbi per petak tidak dipengaruhi oleh varietas, namun dipengaruhi oleh ketinggian tempat. Interaksi antara varietas dan ketinggian tempat tidak nyata.

Dari hasil analisis terlihat bahwa varietas tidak berpengaruh terhadap Bobot umbi per tanaman, namun pada ketinggian tempat $1200 \mathrm{~m}$ dpl varietas Granola dan Supejohn memiliki bobot umbi per tanaman yang jauh lebih tinggi dan memiliki nilai yang hampir sama, yaitu sebesar $44722,40 \mathrm{~g}$ dan $44733,70 \mathrm{~g}$, jika dibandingkan dengan yang di tanam pada ketinggian tempat 750 m dpl sebesar 1429,58 g dan 1256,82 g.

Dari hasil analisis terlihat bahwa pada ketinggian tempat $750 \mathrm{~m}$ dpl hanya menghasilkan rata-rata produksi umbi per petak sebesar 1343,20 $\mathrm{g}(1,34 \mathrm{~kg})$. Nilai tersebut sangat jauh lebih rendah jika dibandingkan dengan produksi umbi per petak pada ketinggian tempat $1200 \mathrm{~m}$ dpl, yaitu sebesar $7462,18 \mathrm{~g}(7,46 \mathrm{~kg})$. Produksi umbi yang tinggi pada ketinggian tempat $1200 \mathrm{~m}$ dpl disebabkan oleh kondisi iklim yang cocok untuk tanaman, misalnya suhu udara $18-21^{\circ} \mathrm{C}$, suhu tanah $15-18^{\circ} \mathrm{C}$ untuk pembentukan umbi, kelembaban udara $80 \%$ $90 \%$, lama penyinaran 12-13 jam perhari, dan curah hujan $1500 \mathrm{~mm}$ pertahun (Pitojo, 2004; Samadi, 2007).

Di daerah dataran rendah atau menengah dengan suhu udara yang tinggi akan sangat berpengaruh pada pertumbuhan dan hasil kentang. Menurut Ewing (1981) dalam Nurmayulis, tekanan suhu tinggi dapat menurunkan hasil umbi kentang melalui dua hal, yaitu pertama, rendahnya laju fotosintesis dalam penyediaan asimilat untuk seluruh pertumbuhan tanaman; kedua, mengurangi distribusi karbohidrat ke umbi sehingga hasilnya rendah.

Produksi kentang yang rendah pada ketinggian $750 \mathrm{~m}$ dpl sesuai dengan hasil penelitian yang dilaporkan oleh Edi (2001), bahwa ketinggian tempat berpengaruh nyata terhadap pertumbuhan, produksi dan keuntungan finansial yang diterima oleh petani. Dilihat dari sumber benih yang diuji, secara finansial sumber bibit unggul layak diusahakan dengan nilai $\mathrm{B} / \mathrm{C}$ ratio sebesar 1,18 , sedangkan bibit lokal $\mathrm{B} / \mathrm{C}$ ratio yang diperoleh hanya 0,30 . Hal yang sama dikemukakan oleh Gunadi (1997), ketinggian tempat berpengaruh nyata terhadap pertumbuhan dan hasil umbi kentang asal biji. Pertumbuhan dan hasil umbi tertinggi dicapai oleh kentang yang ditanam pada ketinggian $1300 \mathrm{~m}$ dpl, diikuti oleh kentang yang ditanam pada ketinggian $1150 \mathrm{~m}$ dpl dan terendah pada ketinggian $750 \mathrm{~m}$ dpl.

\section{KESIMPULAN DAN SARAN}

\section{Kesimpulan}

Laju Tumbuh Tanaman (LTT) rata-rata dan Laju Tumbuh Umbi (LTU) rata-rata varietas Granola dan Supejhon memiliki nilai yang jauh lebih 
tinggi yaitu LTT tertinggi dicapai oleh varietas Supejhon yaitu sebesar $0,001058 \mathrm{~g} \mathrm{~cm}^{-2} \mathrm{hr}^{-1}$ dan $0,001021 \mathrm{~g} \mathrm{~cm}^{-2} \mathrm{hr}^{-1}$, sedangkan varietas Granola pada umur yang sama sebesar $0,000970 \mathrm{~g} \mathrm{~cm}^{-2} \mathrm{hr}$. ${ }^{1}$ dan $0,000920 \mathrm{~g} \mathrm{~cm}^{-2} \mathrm{hr}^{-1}$ pada ketinggian tempat $1200 \mathrm{~m} \mathrm{dpl}$ (Modoinding) dibandingkan dengan ketinggian tempat $750 \mathrm{~m}$ dpl (Langowan). Nilai-nilai LTT yang tinggi akan mengakibatkan nilai LTU yang tinggi dan selanjutnya mengakibatkan produksi kentang yang tinggi pada ketinggian tempat $1200 \mathrm{~m} \mathrm{dpl}$.

Ketinggian tempat berpengaruh terhadap jumlah umbi pertanaman, bobot umbi pertanaman, dan produksi perpetak, sebaliknya varietas tidak berpengaruh terhadap jumlah umbi pertanaman, bobot umbi perpetak, dan produksi perpetak, serta tidak terdapat interaksi antara varietas dan ketinggian tempat. Pada ketinggian tempat $750 \mathrm{~m}$ $\mathrm{dpl}$, kedua varietas menghasilkan rata-rata produksi umbi perpetak sebesar 1343,20 g (1,34 kg), sedangkan pada ketinggian tempat $1200 \mathrm{~m}$ dpl menghasilkan 7462,18 g (7,46 kg).

Berdasarkan nilai-nilai LTT rata-rata, LTU rata-rata, bobot umbi pertanaman, dan produksi perpetak yang sangat rendah dicapai oleh kedua varietas baik Granola maupun Supejhon,sehingga kedua varietas tersebut tidak dianjurkan untuk dibudidayakan pada ketinggian tempat $750 \mathrm{~m}$ dpl.

\section{Saran}

Perlu dilakukan penelitian lanjutan untuk menguji varietas kentang lainnya yang dapat dibudidayakan di daerah dengan ketinggian tempat $750 \mathrm{~m}$ dp

\section{DAFTAR PUSTAKA}

Beukema, H.P. and D.E. Vander Zaag. 1979. Potato Improvement. International Agriculture Centre, Wangeningen.

BPS dan Direktorat Jenderal Hortikultura. 2011. Direktorat Jenderal Hortikultura. www.deptan go.id/infoeksekutif/horti/pdfatap 2011/lp.kentang.pdf.
Edi, S. 2001. Pengaruh Ketinggian Tempat Terhadap Produksi dan Kelayakan Usaha Tani Kentang di Kabupaten Kerinci Jambi. Diakses pada tanggal 8 Agustus 2012.

Gardner F.P.R.B Pearce dan R. L Mitchel. 1991. (terj. Herawati Susilo) Fisiologi Tanaman Budidaya. UI Press. Jakarta.

Gunadi, N. 1997. Pengaruh Ketinggian Tempat dan Bahan Tanaman terhadap Pertumbuhan dan Hasil Kentang Asal Biji Botani. Balai Pengkajian Tehknologi Pertanian Sulawesi Tenggara. Jurnal Hortikultura Vol. 7 No. 2 : 642 - 652. http//katalog.pustaka-deptango.id.

Gunarto, A. 2003. Prospek Agribisnis Kentang G 4 Sertifikat di Kabupaten Sukabumi, Pustaka IPTEK, Jurnal Sain dan Teknologi BPPT VII.1B.07

Handayani, J.S., 2009. Pengaruh Jenis Mulsa Terhadap Pertumbuhan dan Hasil Tiga Kultivar Kentang (Solanum tuberosum $\mathrm{L}$ ) yang Ditanam didataran Medium. J. Agron Indonesia 37(1):14-20.

Midmore, D.J. 1984. Potato (Solanum tuberosum. L) in The Hot Tropics. I. Soil Temperature Effects on Emergence, Plant Development and Yield. Field Crop. Res. 8: 225 - 227.

Nurmayulis dan Maryati. 2008. Laju Tumbuh Umbi dan Kandungan Fosfor Kentang yang Diberi Pupuk Organik Difermentasi Azospirillum sp dan Pupuk Nitrogen. J. Agrivigor 7(3):196-205, Mei-Agustus 2008; ISSN 1412-2286.

Pitojo, S. 2004. Benih Kentang, Kanisius Yogyakarta.

Rogi, J.E.X. 2008. Laporan Penelitian Kentang. Fakultas Pertanian Unsrat Manado.

Samadi, B. 2007. Kentang dan Analist Usaha Tani. Kanisius. Yogyakarta.

Setiadi. 2009. Budidaya Kentang. Penebar Swadaya, Jakarta. 
